\title{
Violence, survival and female resilience in west cote d'ivoire
}

\begin{abstract}
The socio-political crisis of 2010-2011 in Côte d'Ivoire exposed many Guéré women to various forms of violence including rape. These acts of violence resulted in psychological trauma and sometimes mockery and social rejection, against which they had no recourse. They were for this reason in great psychological suffering, which they translated into various somatizations. In order to give those appropriate help, psychosocial counseling sessions were organized in 2014 to support them and facilitate their community reintegration. The present study aims to describe the interventions with these women that allowed them to resist and survive the atrocities they have suffered to continue living. The methodological approach was qualitative of descriptive type and the data collection was done by a semidirective interview and a questionnaire administered to a sample of 38 Guéré women victims of violence and aged from 20 to 65 years. From the activities proposed during the intervention, an analysis can be made of the resilience and survival mechanisms of these women and the data collected showed that the psychosocial interventions provided relief for their psychological distress.
\end{abstract}

Keywords: guéré women, war, violence, survival, resilience, ivory coast
Volume 8 Issue 2 - 2017

\author{
Bissouma AC, 1,2 Kouassi Ettie $S,{ }^{\prime}$ \\ Anoumatacky Apn M, ${ }^{2}$ Soro $J,{ }^{3}$ Yeo Tenena \\ YJM' \\ 'National Institute of Public Health, Cote d'Ivoire \\ ${ }^{2}$ National Mental Health Program, Cote d'Ivoire \\ ${ }^{3}$ Citizenship Initiative, Cote d'Ivoire
}

\begin{abstract}
Correspondence: Anna-Corinne Bissouma, Department of Psychology, National Institute of Public Health, Cote d'Ivoire,
\end{abstract} Email annabissouma@yahoo.fr

Received: July 26, 2017 | Published: September 26, 2017

\section{Discussion}

Armed conflicts are opportunities for the strongest to perpetrate on the weakest, among which women, multiple and various forms of violence. The socio-political crisis of 2010-2011 in Côte d'Ivoire was not the exception. And the western region of the country has been particularly affected in terms of violence against women, although there are no exact number of the women victims of this war. The finding is that many Guéré women, in their flight to more secured areas, have suffered publicly, in the bushes, various violence perpetrated by armed bands. Those who have been held in captivity in camps for months have suffered repeated violence. The various acts of violence were carried out with cruelty, with the use of punches and footings or various objects such as bayonets, ropes, branches of trees or bits of wood, pipes and belts. White weapons (machetes), firearms, glowing cigarettes, or flaming plastic bags (whose melting and burning plastic was poured dropwise on them) also served as torture. These types of violence include physical, sexual and psychological violence. ${ }^{1}$ Thus, rape, constructed as a "weapon of war", was used during the political crises by armed men to terrorize the population, break families, and destroy communities. Whatever the type, violence is a painful experience that permanently affects victims in all areas of their lives, namely physical, psychic, emotional, economic, social, sexual and spiritual, and places them in a state of suffering and of quasiperpetual distress. ${ }^{2}$ This state of suffering is referred to as psychic trauma by many authors who agree to define it as an injury, a violent shock or a sort of short-circuit in the psyche of an individual or group of individuals and is able to deeply destabilize its existence, while overwhelming its possibilities of reaction to face it. ${ }^{3-5}$ According to Salmona, the prevalence of psycho-trauma is higher in women $(10.5$ to $13.8 \%$ ) than in men (5 to $6 \%) .{ }^{6}$ It is clear that the various violence perpetrated by armed gangs on women Guéré during the crisis, led to psycho trauma. To this, were added the mockery of almost all in their community, their marginalization, their stigmatization and their social rejection. Their children suffered as much as they did this mockery and were excluded from the play activities of other children on the advice of the mothers. These hostile reactions forced these women into social isolation and silence and some of them began to develop alcohol and / or tobacco addictions to alleviate discomfort. Martinez et al., ${ }^{7}$ defines survival as the ability of an individual to develop a set of practices to adapt and maximize his chances of survival in face of adversity. According to Lecomte, ${ }^{3}$ individuals can overcome their psychic trauma, even if they have scars. And he calls resilience, this ability to overcome the trauma caused by particularly painful events. Similarly, Anaut ${ }^{8,9}$ defines resilience as the ability to emerge victorious from an ordeal that is traumatic, despite risks, with self-regeneration. However, Rogers $\mathrm{C}^{10}$ argues that resilience is not possible without external assistance. Therefore, in order to help these Guéré women to be resilient, a project of "support for the peaceful reintegration of return in the regions of Guémon and Cavally" was carried out from August to November 2014 in partnership between an Organization Non Governmental (NGO), Initiative Citoyenne, and the National Institute of Public Health (INSP) of Côte d'Ivoire. The aim was to support and facilitate their community reintegration and relief from psychological distress through the implementation of psychosocial support sessions for survivors of gender-based violence (GBV). Thus, by observing and talking with these so-called "Returned" women because they fled their place of life during the war and returned, some questions have arisen: "What adaptive and coping mechanisms have they used to "come back"? And how did the proposed activities help these abused women to survive these traumatic experiences? These are the questions underlying the present study.

\section{Materials and methods}

\section{Method}

In order to promote the reintegration of survivors, the intervention was mainly based on the management of psychological trauma by various activities (clinical evaluation during individual interview, speech group, activities of discharge, relaxation and assertiveness) and support Psychosocial (organization of local groups of listening, accompaniment for the implementation of activities generating income). The prospective study we report is descriptive. 


\section{Location and population}

The activity took place in the regions of Cavally and Guémon in the west of Côte Ivoire. Four localities ${ }^{1}$ were involved in the project initiated. Toulepleu is a town $\mathrm{i}$ of the Moyen-Cavally region, $650 \mathrm{~km}$ west of Abidjan, near the border with Liberia. The department of Blolequin is located in the west of the department of Toulepleu. The population of these departments is predominantly composed of Guéré natives who live together with many non-natives and allochtones, including Yacouba, Baoulé, Mahouka, Sénoufo, Burkinabe, Mauritanians, Guineans.... At each site, women leaders trained in the issue selected a workforce of 63 women identified as victims of violence during the post-election crisis. Of these, 33.33\% were from Toulepleu, ${ }^{11} 26.99 \%$ from Blolequin, ${ }^{12} 23.81 \%$ from Guiglo ${ }^{13}$ and $15.87 \%$ from Duekoue. ${ }^{10}$ This study focuses on the 38 women in the communities of Toulepleu and Blolequin because of the particular characteristics of their stories, the extent of the violence they have suffered, and the mechanisms of adaptation and survival that have been implemented or not. Concerning the women of Guiglo \& Duékoué, ${ }^{1}$ many were victims of recent violence (dating from 20132014) or were looking for secondary benefits by posing as victims.

\section{Tools}

An interview guide assessed the health status of each survivor from a medical, psychological and social perspective. The guide was administered by the team of psychosocial workers with the help of the translators for those who could not communicate in French. The sociodemographic characteristics, the typology of the violence suffered the perception of violence and the status of women, the means used to survive and the attempt to resume normal life were explored...Trauma was evaluated according to DSM IV-TR diagnostic criteria. Following the clinical evaluation, groups of speeches were organized to debrief the participants and session of emotional discharge activities was held.

\section{Psychosocial workers' team and interventions}

The field workers were a psychiatrist, a psychologist and two members of the NGO trained in conflict management. Each session lasted 2days per locality. Each locality benefited from 2 sessions, the gap between each session varied from 1 to 2 months. Between each session, community women leaders were invited to organize the women into a psychological listening and support group to meet weekly. From one locality to another, the modalities of the intervention varied according to the problems we had to face.

Several activities have been carried out in the field:

a. Individual interviews conducted by the psychiatrist and the psychologist with the aim of evaluating the evolution of the psychic state and the social environment of the survivors.

b. Debriefing groups, to build resilience and peer support.

c. Self-listening groups, for sharing experiences between women.

d. Relaxation activities (respiratory control), to help them to manage anxious symptoms.

\section{e. Exercises to promote emotional discharge}

f. Assertiveness exercises with the aim of developing self-esteem and self-confidence.

Maeter and Radcliff have shown the structuring effects of a group system in the therapeutic management of victims of collective violence, enabling the consolidation of a collective identity and memory undermined. From there, it becomes possible for these women to develop a changing individual identity; ${ }^{14}$ the language barrier or the inhibition of women required the presence of a translator at all phases of the session.

\section{Analysed items}

In this work, we first studied the following items: Age, gender, ethnicity, religion, level of education, type of violence (sexual violence, gender-based violence, numbers, place, etc.), the initial diagnosis, the different problems, the expectations and the evolution between the two sessions of psychosocial support. WHO defines sexual violence as: "Any sexual act, attempt to obtain a sexual act, comment or advances of a sexual nature, or acts directed at trafficking or otherwise directed against the sexuality of a person using coercion committed by a person regardless of his or her relationship with the victim, in any context, including, but not limited to, home and work". Acts of sexual violence include rape, sexual slavery, enforced prostitution, forced pregnancy, forced sterilization and any other form of sexual violence of comparable gravity. ${ }^{15}$ Gender-based violence is acts of discrimination perpetrated on the basis of the sex of the person, in this case the female sex. ${ }^{16}$ Secondly, we analyzed the impact of some interventions, the status of women, the resilience and survival of women following the events. The term "resilience" refers to the ability to survive particularly painful events. ${ }^{17}$

\section{Ethics}

Confidentiality and respect for human rights were observed. The women were informed of the different components of the intervention and their agreement was obtained before the activities began. All survivors with psychological decompensation were put on treatment. Social and health issues were referred to the relevant departments.

\section{Results}

\section{Characteristics of the population}

The 38 women of Toulepleu and Blolequin were mostly between 40 and 59 years of age. $42.86 \%$ were in their forties in Toulepleu against $29.41 \%$ in Blolequin and $33.33 \%$ were in their fifties in Toulepleu against $39.41 \%$ in Bloléquin. The distribution according to the ethnic group showed that $81.58 \%$ of the women were Guéré (all the women of Toulepleu were Guéré) and 18.42\% were Malinkés (Mahoukas ethnic subgroup). The vast majority of these women were illiterate (71.42\% in Toulepleu and $64.71 \%$ in Blolequin).

\section{Typology of the violence}

Different forms of violence have been experienced (Table 1). These brutalities were committed between 2011 and 2012. In Toulepleu, some women mentioned events dating back to 2002 and 2003 that they had never spoken of a woman may have experienced several types of violence: physical violence, sexual violence, and psychological abuse. In most cases, it was collective rape $(61.90 \%$ in Toulepleu and $47.06 \%$ in Blolequin), physical violence by beatings (42.85\% in Toulepleu and $41.17 \%$ in Blolequin). The different acts of violence were carried out with cruelty, with the use of punches and footings or various objects such as bayonets, ropes, branches of trees or bits of wood, pipes and belts. White weapons (machetes), firearms, glowing cigarettes, or flaming plastic bags (whose melting and burning plastic was poured dropwise on them) also served as torture. This violence was sometimes committed several times a day, over a day or several months, in the presence of known and / or unknown witnesses. The rapes resulted in 5 pregnant women, 2 gave birth to 
children who had neither received a name at the time of the study, nor were they declared to the registry office. The other pregnancies had not arrived at their terms.

Table I Distribution of types of violence

\begin{tabular}{lll}
\hline Type of Violence & Toulepleu & Blolequin \\
\hline Collective rape & $61,90 \%$ & $47,06 \%$ \\
Individual rape & $9,52 \%$ & $23,53 \%$ \\
Physical violence (assault) & $42,85 \%$ & $41,17 \%$ \\
Torture & $9,52 \%$ & - \\
Witness of murder & $14,29 \%$ & $11,76 \%$ \\
Destruction of property & $9,52 \%$ & $5,88 \%$ \\
Life threatened directly & 4,76 & $11,76 \%$ \\
Forced labor & $9,52 \%$ & $5,88 \%$ \\
Hostage / sequestration & $14,29 \%$ & - \\
Collective sexual exploitation & $4,76 \%$ & $5,88 \%$ \\
Loss of a relative & $14,29 \%$ & - \\
Rape of a relative & $4,76 \%$ & 5,88 \\
Witness of Aggression & - & $5,88 \%$ \\
Domestic Violence & - & $5,88 \%$ \\
View of corpse & - & $23,53 \%$ \\
\hline
\end{tabular}

\section{Diagnostics}

The diagnoses found during the psychopathological evaluation are presented in Table 2. A woman could present several clinical pictures, mostly post-traumatic stress disorder, anxiety disorders and psychotic states. Co-morbidities, such as alcohol, drug, kaolin, were found in $57.14 \%$ of women in Toulepleu and $5.88 \%$ of women in Blolequin. In Toulepleu, $90.48 \%$ complained of health problems against $70.59 \%$ in Blolequin. Women's attitudes were marked by procrastination, passivity and submission at Toulepleu and at Blolequin through attitudes of passivity and autonomy. Concerning social problems, we noticed: a demotivation with inactivity $(13.04 \%)$, precariousness $(52.17 \%)$, and poverty $(26.09 \%)$, lack of shelter $(4.35 \%)$, isolation (13.04\%), and social improvement (8.70\%).

Table 2 Distribution of the various medical and psychological diagnoses

\begin{tabular}{lll}
\hline Initial Medical-Psychological Diagnosis & Toulepleu & Blolequin \\
\hline PTSD & $90,48 \%$ & $47,06 \%$ \\
PTSD resolved & 0 & $5,88 \%$ \\
Traumatic bereavement & $9,52 \%$ & $5,88 \%$ \\
Psychotic Disorders & $29,52 \%$ & 0 \\
Depression & $4,76 \%$ & $11,76 \%$ \\
Anxiety state with somatic expression & $23,81 \%$ & $14,29 \%$ \\
Addiction & $57,14 \%$ & $5,88 \%$ \\
\hline
\end{tabular}

\section{Resilience, survival and evolution}

Toulepleu's women were more pessimistic $(66.67 \%)$ than Blolequin's (29.41\%) and had little social support (9.52\% in Toulepleu compared to $58.82 \%$ in Blolequin). The experience of the women of Toulepleu was more negative than those of Blolequin. The resilience of these women was low, marked by poor quality of relationships with the environment, lack of social support, the impossibility to imagine the future, difficulties to work and a great demotivation. Thus $85.71 \%$ of the women of Toulepleu were not resilient against $17.64 \%$ in Blolequin. The emotional state was marked by various perturbations including the impression of having changed, feelings of humiliation, uselessness...(See graph $n^{\circ} 1$ ) some mechanisms had been mobilized to facilitate resilience. The women of Bloléquin were more resilient than those of Toulepleu, through the mobilization of their internal resources $(29.17 \%)$, their faith $(12.5 \%)$. They also could count on family support (41.67\%), social support provided by an NGO (12.5\%). Thinking about their children $(8.33 \%)$ was also a source of motivation, as be able to benefit from caring attention (8.33\%). Expectations are shown in Table 3. Concerning the evolution, between the two sessions it had stayedgenerally stationary at Toulepleu and was favorableat Blolequin (Table 4). The evolution could only be evaluated with 11 women of Blolequin who sayed feeling better, the others didn't want to participate to the second session.

Table 3 Distribution of patients according to expectations.

\begin{tabular}{lll}
\hline Expectations & Toulepleu & Blolequin \\
\hline Financial assistance & $57.14 \%$ & $64.70 \%$ \\
Socio-economic support for children & $19.05 \%$ & $17.65 \%$ \\
Psychological support & - & $11.76 \%$ \\
Medical care & $47.62 \%$ & $17.65 \%$ \\
Administrative problem & & $5.88 \%$ \\
Repairing her home & $4.76 \%$ & - \\
\hline
\end{tabular}

A woman could have several expectations

Table 4 Distribution of the workforce according to the evolution and the locality

\begin{tabular}{lll}
\hline & Toulepleu & Blolequin (N=I I) \\
\hline Evolution & & \\
\hline Stationary & $71,42 \%$ & $5,88 \%$ \\
\hline In the process of improvement & $28,57 \%$ & $23,53 \%$ \\
\hline Improvement & 0 & $35,29 \%$ \\
\hline Resilience & & \\
\hline Has developed good resilience & $28,57 \%$ & $47,06 \%$ \\
\hline Current resilience & $9,52 \%$ & $5,88 \%$ \\
\hline No Resilience & $61,90 \%$ & $11,76 \%$ \\
\hline Survival & & \\
\hline Builds survival capabilities & $42,86 \%$ & $58,82 \%$ \\
\hline Survival process not activated & $57,14 \%$ & $5,88 \%$ \\
\hline
\end{tabular}

\section{Perception of women's status}

Women were invited to express what they think of the following issues:

I. For you, what is a woman for the guéré?

All the women, a woman is defined by her behavior, she is the one who governs, works, and is courageous. For the Guere a good woman is a person who challenges on all lpart of the familial life, takes charge of herself and to support her husband and her home. She is able to feeding the stranger or her Family in law before her husband comes back from the field. She is the one who seconds her husband and takes care of her children properly. The status of a woman is not related to maternity.

\section{Do you feel like "woman" today?}

The women all said they felt "women" because they looked after their families and children. However, when we highlighted their current experiences, many spoke of the events they experienced during the post-electoral crisis and expressed the outrages they suffered, the fact that they no longer felt like women they no longer had a taste for work and life was difficult. They expressed how war could be destructuring. They spoke of personal difficulties, especially concerning sexuality and social issues mainly the marginalization and stigmatization they suffered. Some mentioned the situation of children who were stigmatized as their mothers. 


\section{Liberating activities}

Debriefing groups helped to build resilience and support for peers. The language barrier or inhibition of women required the presence of a translator at all phases of the session. Many emotions were expressed. Some women collapsed because telling their stories revived their suffering and it was necessary to manage their emotions by respiratory control, in order to maintain the cohesion of the group and its commitment. In spite of the difficulty of the discussions linked to the emotional charge, the group of speech allowed a beginning of sense of the traumatic experience. A feeling of solidarity in the face of suffering was gradually developed. Respiratory control activities have enabled women to manage anxiety symptoms. In each session, a moment was devoted to this activity. In both communities, we offered women two personal development activities

An activity allowing working on self-confidence:

1. In Toulepleu: when we started the activity the women were prostrate physically and psychically. As icebreaker, they were invited to stroll around the room, then stop in front of anyone and look at each other. Initially, the women's faces were closed and tensebut they gradually lit up. If they were shy at the start, they became progressively self-confident and took on the game which had the effect of restarting their body (and from there a beneficial effect on their life could be expected). Later, the instruction was to encourage each other by complimenting them for having survived the events. In turn, they congratulated themselves for their bravery. The aim of this activity was to rehabilitate and restore the survivors in their dignity as courageous human beings and women capable of rising to build better tomorrows.

2. In Blolequin: the same exercise was proposed to the group of women whose voices were low. These women were very timid, withdrawing of the group. The aim of this exercise was to get them out of their shells and thereby upgrade them. They had to pass in turn before each woman and say beautiful words. Thus, they complimented themselves on their physical appearance, on the quality of their participation or on the bravery they showed during the events. This activity was restorative for each of the women present.

The second activity was physical expressions to promote emotional discharge:

\section{1. à Toulepleu: "The act"}

As a result of the various interviews and the groups of the speeches, it was clear from the statements of these women that during the events they had been plunged into a state of impotence and submission. They had been severely abused and their victim status was not recognized. There had been no reparation for the abuses suffered. There were many who lived in obsession that the sexual violence suffered would not be discovered, were silent and had not spoken of their misadventure to anyone. Fear of stigmatization annihilated any attempts to manage trauma. We therefore invited them to do the act or to do the act they wished to do at the time of the violence without having had the opportunity. The women symbolically gave blows to the aggressor sometimes even emasculating him with a machete. The verbal expressions were much sexualized. There was a big discharge of violence with a lot of gesticulation. This physical discharge emotionally relieved the women: oscillating between laughter and tears, they expressed the fact that, finally, they had been able to take revenge of their aggressor, that they had "refunded their blow". The women let the repressed pain going out. Despite the tears they heard, they reiterated their well-being at the end of the session and thanked the intervention team with many blessings.

\section{2. in Blolequin: "The yell"}

Of the different times of speech at Blolequin, there was an experience of impotence but above all clearly that a word had been killed, repressed, not expressed for fear of suffering even more abuse, speech or scream of distress repressed to not reveal the hiding place or because no aid appeared on the horizon. The isolation in which the women had been plunged had rendered a potential call unnecessary. The order of the discharge was thus to decontrol the cry or the word which they would have free at the moment of the event. The women released a powerful or fearful cry, a word of conspiracy to exorcise the feeling of helplessness. Liberatory cry, delivered word, these shouts led to a flood of tears that acted as purifier of the sullying, the disgraces they lived. The women of Blolequin appeared to us generally better integrated than those of Toulepleu with better capacities to take care of themselves.

\section{Comments}

The war exposes women to multifaceted experiences marked by separations, loss of family members, physical and economic insecurity, increased risks of sexual violence, injury, detention, deprivation and even death. ${ }^{15}$ Suffering will express itself differently in each of them, as we have seen. Their needs to cope with the disorders induced by these situations are variable as we have seen. The work carried out during these missions was interesting but difficult because of the importance of the suffering of women, the precariousness of their situation. Important social rejection and stigma have weighed heavily, as have their many expectations. The short time of the mission (2days) couldn't allow to face to all requests and to implement enough actions for a good digestion of the traumatic events. The severity of psychological trauma requires several interventions, which were not covered by the project's terms of reference. One of the difficulties was also linked to the Ebola epidemic on the other side of the border, constituting a major stressor. None of the women had actively participated in the conflict as a combatant, their participation had been passive, especially for those who were sexually exploited or enslaved. From a socio-demographic point of view, our results are comparable to those of Rubuye Mer concerning women victims of war in the Congo, notably concerning the preponderance of collective rapes in wartime, the use of various objects to commit sexual violence, place of exaction as often a public place. However, this author testifies to the psychological assistance of the victims. ${ }^{18}$

\section{Victims and Survivors of Violence}

WHO defines organized violence as all actions carried out by organized groups (military, police, and local militias) with the aim of intimidating, terrorizing and violating anyone who may be subject under their power. ${ }^{13}$ The definition proposed by the WHO includes acts of torture and other cruel, inhuman or degrading treatment. It includes imprisonment without trial, executions, hostage-taking, disappearances, any other form of deprivation of human rights, as well as the massive displacement of people caused by organized violence. It is a strategy of terror and brutality that divides society between "aggressors", "victims" and "witnesses" and which most often takes place in a climate of impunity. As a result, Rousseau ${ }^{15}$ asserts that organized violence breaks social ties. The notion of social suffering is used to talk about the biopsychosocial consequences of organized violence. Social suffering considers experience to be both a social and individual phenomenon and looks at the victimization and 
revictimization from power institutions and dominant discourses. The social response refers speeches and interventions set up for survivors, and revictimization refers to the experience of secondary victimization arising from these social responses. This traumatic experience lived by these women confronted them with unspeakable horror. Collateral damage such as loss of good reputation and status, loss of property, bereavement, separations and recurring health problems are all sequels that will not disappear easily, especially since the reaction of the environment was very unfavorable by the rejection and significant stigmatization. There is an extension of the effects of war in of everyday life and a return to a supposedly normal life becomes an illusion, perpetuating so another process of dehumanization. Some women have returned to their communities where they are struck by looks, words, attitudes. An internal turmoil, regularly revived, gave birth to a new terror and an impossibility to overcome the trauma. War and conflict are becoming more and more widespread, crystallizing a victim status that cannot be overcome because it is often overhauled by the reactions of the community or by the interventions of national or international NGOs that make victimization a reality. Thus the violence continues in the words about their destiny, in the looks and rejection of society or in the label of "raped woman" that is stuck to them. Speaking of the Ivorian crisis, M Miran-Guyon ${ }^{19}$ wrote:

"The violence has become commonplace, the frontier between good and evil, the war can only be declined in the tragic register.. Can't we think that, at bottom, every war remained individual, inside of oneself? Attacks on the sacredness of life by all-out violence are compounded by attacks on the dignity of death. How can one struggle for a dignified life when it is not evident to keep oneself alive at first? When it is not even possible to be buried properly, in a country where, in all religious and philosophical traditions, a good funeral is necessary for all?"19 these words testify to the internalization of violence and the conflictuality that it is to continue living. Thus, in the Cavally-Guémon, the violence continues in the words, the looks and the rejection of society. "You are the women of the rebels who are concerned, your names have arrived in Abidjan", that is what heard a women of Toulepleu as she arrived for the session 2. This sentence is pronounced by another woman who was not included in the project. Words are accusers, they strike and brutalize, carrying a jealousy which dares to express itself with open face, especially because in popular thought, any aid from an NGO is subordinated to financial aid that attracts many people. This undoubtedly explains the high rate of false cases that we observed in Guiglo and Duékoué. ${ }^{1}$ This form of violence echoes sexual violence as defined by $\mathrm{WHO}^{15}$ Violence has also been exerted on the conception, on the motherhood, on the childbearing and childhood of a child born from a woman and from war and violence. They have been conceived, really or imaginedly, in violence and from violence, and it is by this violence that they are referred to the mother. This violence is expressed by the non-affiliation of the child, by his non-naming which appears as a refusal of his existence because the child also incarnates the shame of the violence suffered so its existence blocks repression and forgetfulness. Society takes care of children born before the crisis, it vilifies them to have a mother abused and from the opprobrium of the mother arises that of the children who are pointed at as if they should have been no more of this mother. This attitude of the community calls for disaffiliation and disenfranchisement of the woman victim and survivor. The violence recreates itself and invents itself in the daily life of its women as if to the crime of having been raped, mistreated, tortured was added that of having survived and especially of returning from the hell. Children pay a heavy price for the mother's courage. For the society, the woman who is the victim of violence is not a victim to avenge, but a culprit to be excluded and hidden. ${ }^{20}$ In most African societies, sexually abused persons are found guilty of acts perpetrated against them. So, they are convicted to silent to avoid social rejection. Rape produces feelings of humiliation and shame not only in the raped woman but also in all her entourage. Socially stigmatized, these women and their families feel difficulties in the relationships they establish with the members of the group. ${ }^{21}$

\section{Resilience and survival to female in the country}

\section{What adjustment strategies did these women develop?}

A Toulepleu, wrapped in silence, many were advancing in the shadow of their life seemingly motivated by this idea "I keep silent on what I have suffered", scared at the idea of public humiliation. To cope and rehabilitate, some were trying to resume a normal life with normal sexuality even if the sexual act was painful and lived as violent. At Blolequin, to confront the accusing fingers, the vast majority of women had chosen to do with and try to move forward. Most of them had returned to work to overcome the rejection and stigma that are the prerogative of women victims of violence. At the first session, we found how the community's social response alters resilience. From there, the process of survival is corrupted because these women, instead of mobilizing energy to give meaning to their existence, strive to overcome hostility that takes many forms and faces. The adversity that women face, after the conflict, is the opprobrium and the rejection of the village or rural community. Thereby, women generally tended to live isolated emotionally and socially, hiding their traumatic experience. Thus, the difficulty for Guéré women to write their history in a of collective victimization's storie was like a resistor on their resilience and reinforced their isolation. There is therefore a double revictimization of women:

\section{a. Rejection of the community}

\section{b. NGO identification as "raped woman", reinforcing stigma}

Like J. who was the only woman raped from her village community. As soon as a national or international NGO arrived in the region to take charge of the GBV, all the fingers pointed in her direction, calling it "raped." Prostrate, furtive, considering that she had few intellectual faculties; $\mathrm{J}$ was retreated behind a wall made of incomprehension and pain, wearing a gloomy outfit, refusing to talk in French, speaking in a low voice. After the first session, where the others women detected her suffering, another wall, now protecting, had risen. These women were a barrier and a buffer between $J$ and his community. From there, a smile was born, a decrispation could begin. In the second session, she is a more open woman, accepting to speak in French despite her linguistic mistakes and hesitations. Her life could now find meaning. It is therefore necessary to question the psychosocial interventions that took place in the west of the country for nearly two decades... focusing on the victimization of the victims and on their vulnerability. Did they not herd these populations into a situation of extreme dependence reinforcing and crystallizing their status of victim? The results obtained by this intervention corroborate those of Roisin, ${ }^{22}$ which focus on individual listening and groups of speech as means of helping the suffering victims.

One of the obstacles to the activities we have tried to set up was what we should call "politics of the outstretched hand". At Toulepleu, more than at Blolequin, women were complying with a certain passivity waiting for funding from NGO IC to develop income-generating activities when they didn'tresume their agricultural activities to feed themselves and their families, while they had land to. The example of Marguerite is edifying: Marguerite lives in a village near Toulepleu, 
her house is on the roadside. She is waiting for an NGO to build a roof for her, because UNHCR and another international NGO have already built the walls... She does not even think of making a roof in papot1 (as seen in the region). She spent her days selling and drinking koutoukou2. It therefore appears that the survival of women has never been emphasized or promoted. The title of the project we had to carry out on the ground, which was addressed to survivors, had led us to meet only victims. How could we help them to change or perceive another way of being? None of Toulepleu's women were on a quest for meaning to understand the experience she lived. They were very passive. At Blolequin, those who asked this question were essentially the Malinke women. They were the only ones to have tapped into their internal resources to resume their commercial activities and spontaneously asked for medicationthey can buy to sleep better. It was at Blolequin that we actually met women who tried to surviving. That why we considered that women at Blolequin had better abilities to take care of themselves and the best integration despite an environment equally deleterious.

According to Martinez, the ability to develop a set of practices to adapt and maximize one's chances of survival is implicit in the notion of survivor who is more positive and less stigmatizing than the notion of victim who conveys an image of weakness, impotence and subservience ${ }^{7}$ To analyze survivorship is

${ }^{1}$ The papot is a form of braiding of branches of palm tree that makes them more watertight.

\section{${ }^{2}$ Traditional alcohol made from palm sap.}

Therefore to take an interest in the active response of survivors to face adversity and the factors contributing to adaptation. So promoting the survival of these women, required that we motivated action to arouse a new hope, while working the sense of traumatic experience to bring a different light on their existence women. This new dynamic was also aimed at fostering their resilience by drawing from the bottom of their hidden resources, transforming the obstacle into a springboard and fragility into wealth. This has allowed them to build a positive relationship with themselves, in the sense of self-reliance, self-respect, self-affirmation to regain consciousness of dignity, courage and value. Speech groups have been a field of deployment of speech for feminine being. In closed spaces, these groups allowed a speech to be delivered and an emotional discharge welcomed by the group of women supported by the therapists (two women). Thus, the group of speech opened a place, a period where the unspeakable could be said, where the femininity and the feminine being were enthroned that no man could threaten by his masculinity or by his phallic word. In this time, a discursive diversion, allowed us to scrutinize the relationship to sexuality and try to understand to the passivity observed in front of sexual violence. Pavec rightly mentions all the limitations imposed on women and their struggle to implement survival modalities which, in periods of decline, can oppose the absolute of an apocalyptic disappearance. Subsequently the setting up of self-listening group and support group, by continuing the psychic work initiated, acted as a factor of resocialization. Indeed, at the heart of these groups, the sharing of experience and mutual support as well as the weekly meeting of these groups acted as a temporal compass, giving them a purpose and an activity. The social bond was thus recreated. The intervention by working on their self-assertion had given them the ability to raise their heads.

\section{Conclusion}

The objective of this study is to describe the intervention in psychosocial support given to women victims of violence during the
2010-2011 socio-political crisis and its impact on their survival and resilience mechanisms. The evidence showed that this intervention had a more positive impact on those of Blolequin compared to those of Toulepleu. Thus, the resilience of women victims of sexual violence is low, while that of their counterparts who are victims of physical and psychological violence is high. It was important to find in each history of victimization and suffering, where a history of resistance was. As Rogers $\mathrm{C}^{10}$ says, human beings possess vast, sometimes ignored, resources which, with external help, can overcome his psycho trauma; And Cyrulnik and Seron, ${ }^{23}$ add that the capacity to resist psychically the trials of life lies in the relations with others.

\section{Acknowledgments}

None.

\section{Conflicts of interest}

Author declares there are no conflicts of interest.

\section{Funding}

None.

\section{References}

1. N'goran KL, Bakayoko I, Joceline Boli AN. Conception magicoreligieuse des agressions sexuelles et du Viol Des filles de 04 Mois à 18 ans à l'ouest de la Côte d'Ivoire (Duékoué et Guiglo). European Scientific Journal. 2016;12(2):1857-7881.

2. Lopez G. Les conséquences des psychotraumatismes. Dunod, France. 2006

3. Lecomte J. La résilience. Résister aux traumatismes. Sciences Humaines. 1999;214.

4. De clercq M. Les traumatismes psychiques. Masson, France. 2001. p.348.

5. Fischer GN. La trace de l'autre, médiation sur le lien humain. Odile Jacob, France. 2005. p.1-202.

6. Marianne Kedia, Aurore Sabouraud-Séguin. L'aide mémoire en psycho traumatologie. (2nd edn), Dunod, France. 2008. p.1-304.

7. Martinez E. Survivre à la violence organisée : parcours et témoignage de deux femmes rwandaises. Université de Montréal, Canada. 2010. p.1-140.

8. Anaut M. L'Humour, entre le rire et les larmes: Traumatismes et résilience. Odile Jacob, France. 2014. p.1-208.

9. Anaut M. La résilience en situation de soins: approche théoricoclinique. Recherche en soins infirmiers. 2004;77:9-19.

10. Rogers C. Approche centrée sur la personne: pratique et recherché. ACP-PR, France. 2008.

11. Pavec N. A l'horizon, la guerre : résistance, insistance, survivance dans “Three Guineas" de Virginia Woolf. 2011;(1938) L'atelier 3(2).

12. Rousseau $\mathrm{C}$. Les réfugiés à notre porte: violence organisée et souffrance sociale. Criminologie. 2000;33(1):185-201.

13. Women and War. International Committee of the Red Cross, Switzerland. 2015.

14. Maeder CD, Ratcliff BG. Traumatisme psychique chez des femmes en exil : un dispositif de soin groupal. L'autre. 2011;12(3):327-40.

15. Sous la direction de, Etienne G Krug, Linda L Dahlberg, et al. Rapport mondial sur la violence et la santé. Organisation mondiale de la Santé, Switzerland. 2002. p.1-404. 
16. Jaspard M. III. Les violences sexuelles. (2nd edn), Les violences contre les femmes, France. 2011. p.63-84.

17. Lecomte $\mathrm{J}$. La résilience, Se reconstruire après un traumatisme. Rue d'Ulm, France. 2010. p.1-61.

18. Rubuye Mer S, Flicourt N. Femmes victimes des violences sexuelles dans les conflits armés en République Démocratique du Congo. Sexologies. 2015;24(3):114-121.

19. Miran-Guyon M. Cyclone post-électoral. Journal des anthropologues. $2011 ;(124125): 373-380$.
20. Boukobza C. La mère, la guerre et l'enfant. Figures de la psychanalyse. 2011;22:67-77.

21. Josse E. Violences sexuelles et conflits armés en Afrique. Résilience Psy, Europe. 2013.

22. Roisin J. Victimes d'agressions sexuelles. Les ressources thérapeutiques des groupes de parole. Stress Trauma. 2003;3(3):163-175.

23. Cyrulnik B, Seron C. La résilience ou comment renaître de sa souffrance. Fabert, France. 2004. p. 1-248 